\title{
Using Spatial Information Technologies as Monitoring Devices in International Watershed Conservation along the Senegal River Basin of West Africa
}

\author{
Edmund C. Merem ${ }^{1 *}$ and Yaw A. Twumasi ${ }^{2}$ \\ ${ }^{1}$ Department of Urban and Regional Planning, Jackson State University, Jackson, MS 39211, USA \\ ${ }^{2}$ Department of Advanced Technologies, Alcorn State University, 1000 ASU DR. \# 360 Alcorn State MS 39096, USA \\ *Correspondence to Dr. Edmund C. Merem. Email: edmund.c.merem@jsums.edu
}

Received: 18 September 2008 / Accepted: 08 December 2008 / Published: 31 December 2008

\begin{abstract}
In this paper, we present the applications of spatial technologies-Geographic Information Systems (GIS) and remote sensing - in the international monitoring of river basins particularly analyzing the ecological, hydrological, and socio-economic issues along the Senegal River. The literature on multinational water crisis has for decades focused on mediation aspects of trans-boundary watershed management resulting in limited emphasis placed on the application of advances in geo-spatial information technologies in multinational watershed conservation in the arid areas of the West African sub-region within the Senegal River Basin for decision-making and monitoring. While the basin offers life support in a complex ecosystem that stretches across different nations in a mostly desert region characterized by water scarcity and subsistence economies, there exists recurrent environmental stress induced by both socio-economic and physical factors. Part of the problems consists of flooding, drought and limited access to sufficient quantities of water. These remain particularly sensitive issues that are crucial for the health of a rapidly growing population and the economy. The problems are further compounded due to the threats of climate change and the resultant degradation of almost the region's entire natural resources base. While the pace at which the institutional framework for managing the waters offers opportunities for hydro electricity and irrigated agriculture through the proliferation of dams, it has raised other serious concerns in the region. Even where data exists for confronting these issues, some of them are incompatible and dispersed among different agencies. This not only widens the geo-spatial data gaps, but it hinders the ability to monitor water problems along the basin. This study will fill that gap in research through mix scale methods built on descriptive statistics, GIS and remote sensing techniques by generating spatially referenced data to supplement the existing ones for the management of the Senegal River Basin. The results show the incidence of change predicated on pressures from demography, natural forces and the proliferation of river basin development which resulted in more irrigated areas to meet the needs of the inhabitants of the basin. With the substantial increase in bare surface areas, the basin faces growing exposure to the threats of desertification.
\end{abstract}

Key words: GIS, remote sensing, international watershed, monitoring, river basin

\section{Introduction}

Over the last several years, the Senegal River watershed in a Sahel ecozone continues to experience recurrent cases of drought as a result of climatic variability and a host of other factors in the face of severe poverty and misery [1,2].This comes at a time when the need for regular geospatial assessments of environmental impacts of the harsh climatic conditions of the basin along with other problems have been overshadowed by emphasis on food security and conflict resolution in trans-boundary watershed management. In this paper, we present the need 
for an integrated GIS and remote sensing approach in the multinational conservation of river basins particularly by analyzing ecological, hydrological and socio-economic issues along the environment of the Senegal River Basin in West Africa. According to the literature, recent technological advances have brought remote sensing and GIS techniques to the forefront of management as viable decision support tools for conservation [3]. In the process, integrated watershed assessment, built on remote sensing, has in recent times not only emerged as a recognized system in nations around the Southern hemisphere, but it is proving to be a vital segment of riparian ecological planning. While remote sensing succinctly tracks watershed attributes and land use with minor limitations [4]. Environmental modelers have been blending GIS data management and processing ability in the analysis of watershed systems for quite some time. This capability remains indispensable in the design of data infrastructure best suited for watershed analysis [5], and the conservation of natural resources to sustain development [3].

Having said this, let it not be forgotten that the literature on multinational water crisis has for decades focused on the politics and mediation aspects of transboundary watershed management [6]. This has resulted in limited emphasis on the applications of geo-spatial information technologies in multinational watershed conservation in the arid areas of West African sub-region within the Senegal River Basin for decision-making and monitoring. Notwithstanding these defects in the literature and other problems, the ecological and economic importance of the basin to the life of the region's inhabitants deserves some attention. The basin not only contains sensitive natural habitats that are essential for biodiversity in the delta, but since the last three decades, hydro development activities in the area have been seen as a catalyst to boost the economies of the riparian states in the basin [7]. In the area of agriculture, Senegal River Basin pasturelands are essential for livestock raising and grazing, which remain a major economic activity in the basin. The citizens of the region depend on the flood plains for fishing and other income yielding activities to sustain their daily lives. Notwithstanding the basin's role as a source of life support in a complex ecosystem stretching across different nations in a mostly desert region characterized by water scarcity and subsistence economies, there exists recurrent environmental stress induced by both socio-economic and physical factors [8].

Accordingly, the environmental concerns in the region consist of invasive weeds and eutrophication in some places in the valley and the delta. Other evidence of environmental problem takes the form of increased salinity, drying up of water due to the destruction of water inflow channels from the construction of dikes and irrigated areas as well as stream habitats pollution due to the discharge of industrial and agricultural effluents. The basin also experienced a rapid decline in rain fall during the 1960 s and 1970 which resulted in the degradation of much of the overall natural resources, drop in ground water level and disappearance of pasture land. Under these harsh conditions, the local inhabitants did not produce enough to survive and the only alternative was emigration $[9,1]$. Considering the problems of flooding and limited access to sufficient quantities of water, the costs of these devastations continue to weigh heavily particularly on the health of the rapidly growing population and the economy. The issues are further compounded due to all of the threats of climate change and the resultant degradation of almost the region's entire natural resources base $[10,11]$. In light of these concerns, food security for a growing urban population and the monitoring of droughts are considered top priority in policy interventions of organizations involved in the management of the basin. Institutional response to these difficulties through the building of dam was implemented, to control stream flow and allow the conversion of huge areas of land for farming and hydropower plants to meet energy needs [11]. While the institutional framework for managing the waters offer opportunities for hydro electricity and irrigated agriculture through the building of dams, it has raised other serious concerns in the region most notably ecosystem decline and the proliferation of water borne diseases at an endemic proportion [1, 16].

In a region prone to poverty and economic misery $[12,13]$, watershed based research is often hindered by a lack of access to adequate data infrastructure. This not only widens the geo-spatial data gaps, but it limits watershed monitoring. At the same time, there exist numerous studies that attest to the application of geospatial information system in watershed management. In one study, Prakash [14] identifies the usefulness of this novel device due to its capability to track fundamental elements shaping the general development and management of a basin, while ensuring minimization of future resource degradation through the adoption of suitable conservation measures. The applications of geoinformation techniques of GIS and remote sensing analysis in these settings [4] help capture the effects of poor stewardship of the environment from extreme anthropogenic activities that trigger ecosystem disturbance in places such as the Senegal River basin. In the context of the study area, the focus is to apply the latest advances in spatial technologies in order to ensure the efficient management of the Senegal River Basin.

\section{Aims, Organization and Objectives,}

This paper focuses on the applications of GIS and remote sensing techniques as monitoring tools in multinational watershed conservation. Emphasis is on a review of the issues, methods, framework and a case study of environmental analysis under the rubric of hydrology, socio-economic and physical elements. This will be followed by examination of the current management framework in the region and some future policy recommendations. The paper has five parts. The first portion contains the introduction and background information. The second part highlights study area 
background and methodology. Part three presents the results of the data analysis, discussion of the findings while part four identifies the current framework in the conservation of the basin. In part five, the paper provides some recommendations and concluding statements of the project. The paper has five major objectives that encompass an initial aim to contribute to existing literature. The second aim is to apply the latest advances in geospatial technology to watershed management. While the third objective is to analyze the socio-economic and ecological issues confronting the basin, the fourth objective is to assess the framework for managing the basin. The fifth objective is to design a decision support tool for managers in the region.

\section{Overview of Study Area}

Study Area

The Senegal River basin shown in Figures 1 and 2 located in West Africa between latitudes 10'30 and 17'30 $\mathrm{N}$ and longitudes 7' 30 and $16^{\prime} 30 \mathrm{~W}$, is the second longest river in the region.

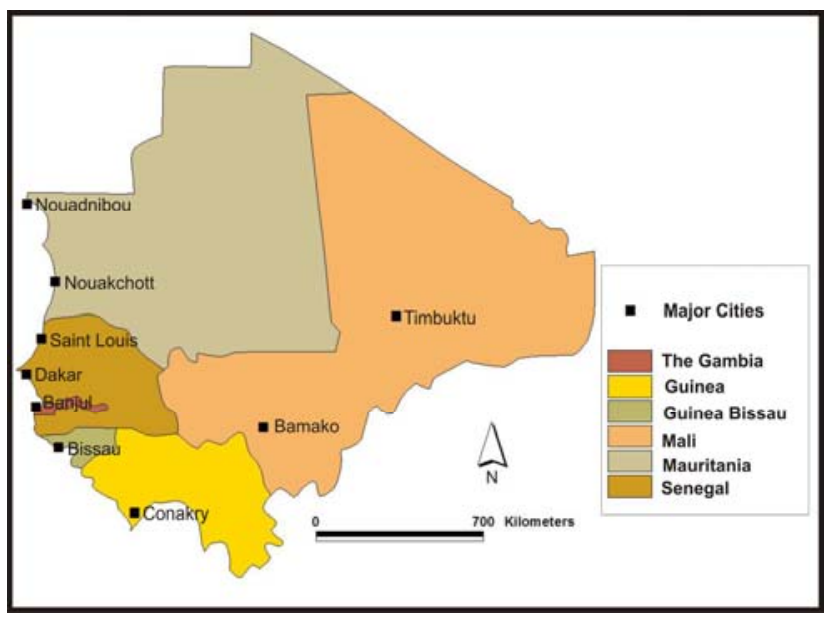

Figure 1: the Study Area: The Senegal River Basin Nations

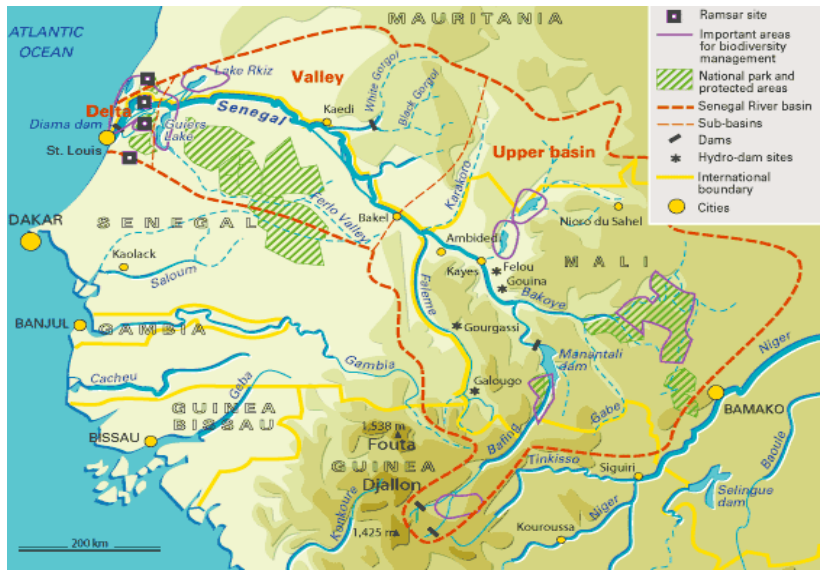

Figure 2: the Ecological Features of the Senegal River Basin
Table 1: Hydrological characteristics of the Senegal River Basin

\begin{tabular}{|c|c|c|}
\hline \multicolumn{2}{|c|}{ Surface area of the Basin } & $300,000 \mathrm{~km} 2$ \\
\hline Annual & recipitation & $600 \mathrm{~mm} /$ year \\
\hline \multicolumn{3}{|c|}{ Annual runoff Bakel Station } \\
\hline Before & 1985 & $698 \mathrm{~m} 3 / \mathrm{s}$ \\
\hline After & 1985 & $412 \mathrm{~m} 3 / \mathrm{s}$ \\
\hline \multicolumn{3}{|c|}{ Annual Discharge Bakel Station } \\
\hline Before & 1985 & $863 \mathrm{~m} 3 / \mathrm{s}$ \\
\hline After & 1985 & $416 \mathrm{~m} 3 / \mathrm{s}$ \\
\hline
\end{tabular}

The River basin as Table 1 indicates covers 300,000 $\mathrm{Km} 2$ with annual precipitation of $600 \mathrm{~mm}$. It is shared by 4 nations most notably Guinea, Mali, Mauritania and Senegal. The breakdown of the physical attributes shows $31,00 \mathrm{~km} 2$ (11 percent) of the basin in the Northern plateau of Guinea while $155,000 \mathrm{~km} 2$ (53 percent) are situated in Western Mali. The others include $75,500 \mathrm{~km}$ in Southern Mauritania which accounts for 26 percent of the watershed while the remaining $27,500 \mathrm{~km}$ in Northern Senegal represent 10 percent of the basin (Table 2).

Table 2: Summary of physical data characteristics

\begin{tabular}{|c|c|c|c|c|c|}
\hline \multicolumn{2}{|c|}{$\begin{array}{l}\text { Physical } \\
\text { Attributes }\end{array}$} & Mali & Mauritania & Senegal & Guinea \\
\hline \multirow{3}{*}{$\begin{array}{l}\text { Surface } \\
\text { area } \\
\left(\mathrm{km}^{2}\right)\end{array}$} & National & $1,246,574$ & $1,030,700$ & 97,000 & 245,857 \\
\hline & Basin & 155,000 & 75,500 & 27,500 & 1,000 \\
\hline & $\begin{array}{l}\% \text { of } \\
\text { Basin }\end{array}$ & 53 & 26 & 10 & 11 \\
\hline \multirow{2}{*}{$\begin{array}{l}\text { Rainfall } \\
\text { annual } \\
\text { average }\end{array}$} & National & 850 & 290 & 800 & 2,200 \\
\hline & Basin & 300 to 700 & 80 to 400 & $\begin{array}{c}150 \text { to } \\
450\end{array}$ & $\begin{array}{r}1,200 \\
\text { to } 2000\end{array}$ \\
\hline \multirow{2}{*}{$\begin{array}{l}\text { Temp- } \\
\text { erature }\end{array}$} & $\begin{array}{l}\text { National } \\
\text { average }\end{array}$ & 29 & 28 & 29 & 26 \\
\hline & $\begin{array}{l}\text { Basin } \\
\text { mn and } \\
\max \end{array}$ & 15 to 42 & 18 to 43 & 17 to 40 & 10 to 33 \\
\hline
\end{tabular}

The River originates in the Fouta Djallon Mountain high lands of Guinea and flows through Mali, before forming the boundary between Mauritania and Senegal to its estuary on the Atlantic Ocean. As the lifeline in the Sahel, the drainage length stretches through an area measuring 1,800 kilometers $(\mathrm{km})$-long. The river and the surrounding valley have supported its population variably throughout the centuries despite very harsh climatic conditions [2, 9]. The basin has three distinct parts: 1) the upper basin, which is mountainous, 2) the valley and the delta which are sources of biological diversity and 3) wetlands (Figure 2). In the three distinct parts of the basin 
where changes in topographical, hydrological and climatic conditions are quite extensive, rainfall occurs from AprilOctober, while river flooding intensifies between July and October. With much of the flood water originating in the upper valley, during the annual flood, large areas of floodplains are inundated but the area covered varies greatly from year to year. For more information on rain and temperature of the area refer to Table 4.

As a region with a sub Saharan desert climate that was constantly barraged by long periods of drought during the 1970s, its people were forced to leave the valley in the face of massive starvation and conflict [9]. During the last few decades as this fragile valley continued to face several climatic problems in the form of severe droughts, extreme population growth, economic decline and unstable food security, there were numerous mass migrations, mainly to the mushrooming cities such as Dakar, Bamako, Conakry and Nouachott with enormous pressures on water resources [2]. In these places, access to large volumes of drinkable water is not only a touchy concern but is critical for the welfare of the populace and the region's economy. Based on the current prognosis on climate change, the situation in the area will be compounded in the near future as a result of desertification already threatening the basin [15].

Over the years, the hydrology of the Senegal River system has changed due to the construction of two dams to alleviate the problems. The Diama Dam, located $27 \mathrm{~km}$ upstream of St Louis in Senegal and completed in 1985, was designed to prevent the intrusion of saline water from the Atlantic Ocean $[11 ; 16,17,7]$. On the other hand, the Manantali Dam in Mali, about $1200 \mathrm{~km}$ upstream of St Louis, is a hydro-electric dam completed in 1988. With the idea behind the two dams centered on the expansion of irrigated farming along the Senegal River and the delta coupled with electricity generation for urban and industrial development and river navigation [8], the completion of the dams resulted in negative externalities at the expense of the local population [18- 21, 7, 17] In fact most people along the delta area suffered the menace of floating aquatic weeds as well as salinization. Even though fishing among the local people has been reported as increasing along the upstream part of the river, construction of the Manatali Dam prevented annual floods needed in traditional recession agriculture [22, 23].

Regarding socio economic indicators, of the 35 million residents of the area, Mali and Senegal have a slightly identical population of 11 and 10 million, respectively, with Mauritania accounting for 3 million (Table 3). Among the Basin's population, of the two million people that live in the Senegal River watershed, about $85 \%$ of them rely on the watershed for their livelihoods while approximately 700,000 in riparian communities of the Middle Valley depend on the estuarine environment. The livelihoods of these communities are largely based on traditional production systems mostly linked to the annual flooding cycle. With the population growth of the basin increasing at a rate of about 3 percent per year and slightly higher than the individual averages for the three member states (Table 3), [9,2], countries along the basin remain the worlds' poorest in relation to both the economy and human capital. Out of 174 countries, Mali ranks $166^{\text {th }}$; Senegal ranks $153^{\text {rd }}$; and Mauritania ranks $149^{\text {th }}$ in human development. In terms of UNDP's human poverty index, of 90 developing countries, Mali ranked 87th; Mauritania ranked $77^{\text {th }}$; and Senegal ranked 80th [12].

Table 3: Summary of Socio-Economic Variables

\begin{tabular}{|c|c|c|c|c|}
\hline $\begin{array}{l}\text { Socio- } \\
\text { economic } \\
\text { indicators }\end{array}$ & $\begin{array}{l}\text { Senegal } \\
\text { River } \\
\text { Basin }\end{array}$ & Mali & Mauritania & Senegal \\
\hline $\begin{array}{l}\text { Population } \\
\text { (million } \\
\text { inhabitants) }\end{array}$ & 35 & 11 & 3 & 10 \\
\hline $\begin{array}{l}\text { Annual } \\
\text { Growth Rate } \\
(\%)\end{array}$ & 3 & 2.97 & 2.9 & 2.8 \\
\hline $\begin{array}{l}\text { Urbanization } \\
\text { rate }(\%)\end{array}$ & NA & 41 & 53 & 51 \\
\hline $\begin{array}{l}\text { Farmland } \\
\text { area }\end{array}$ & 823,000 & NA & NA & NA \\
\hline $\begin{array}{l}\text { Irrigated Land } \\
\text { (ha) national } \\
\text { total } \\
\text { Part in Basin }\end{array}$ & NA & $\begin{array}{c}78,630 \\
4,000\end{array}$ & $\begin{array}{c}49,2004 \\
44,449\end{array}$ & $\begin{array}{l}71,400 \\
67,830\end{array}$ \\
\hline $\begin{array}{l}\text { Cattle x 1,000 } \\
\text { units }\end{array}$ & 2,700 & 6,427 & 1,394 & 2,927 \\
\hline $\begin{array}{l}\text { Sheep and } \\
\text { goats }\end{array}$ & 4,500 & 15,986 & 10,850 & 8,330 \\
\hline Fish catch & $\begin{array}{c}26,000 \text { to } \\
47,000\end{array}$ & 100,000 & 520,000 & 395,000 \\
\hline
\end{tabular}

With population growth, urbanization and development of human capital already putting extra pressure on river development action in the basin, the proportion of people living in urban areas continues to be highest in Mauritania at 53 percent, followed by Senegal with 51 percent and Mali under 41 percent (Table 3). Considering that the capitals of these countries are about to grow in the future at astronomical rates, the population of Dakar has been projected to increase from the current 2.4 million to 4.5 million by 2015 [13]. Similar levels of growth rates have been predicted for Bamako and Nouakchott [1].

To oversee the affairs of the watershed, the coordination of management activities of the basin falls under the Organization for the Development of Senegal River; or Organization Pour La Mise En Valeur Du Fleuve Senegal (OMVS) often cited as a successful model of regional cooperation for the management of internationally shared water courses [9]. In 1963, shortly after independence, the nations signed the Bamako Convention for the development of Senegal River Basin. The convention declared the Senegal River an 
international river and created an interstate committee to oversee its development. Driven by a strong will to cooperate, the countries signed the Labe' Convention that created the organization for Coastal States of Senegal River (OERS) in 1968. The mandate focused on the development of the basin by facilitating closer coordination beyond water and agricultural sectors. In the following decade, the OMVS came into operation in 1972 with a mission to accelerate economic development through the promotion of interstate cooperation among the riparian countries [24].

Under the initial arrangements, Mali's principal interests centered on the maintenance of river levels so as to obtain navigable access to the sea and energy produced by the Manatali Dam. The Mauritanian and Senegalese interests on the other hand converge on the need for power production and irrigation in order to improve livelihoods for local populations [25]. These varied interests are typical of a transboundary water management situation and the underlying framework. With the mandate of OMVS compounded by numerous challenges [26], the growing threats posed by changing demographics and widespread poverty[12,13] to the basin's surrounding hydrology and natural environment [16] now makes the application of geospatial information systems in the management of the basin more urgent than ever. Under this setting, GIS and remote sensing techniques are indispensable in the development of resource management tools for effective policy making and monitoring of the river basin.

Half of the basin is located in Mali, but the main input in terms of water resources comes from the upper basin in Guinea with an average of 1,600 mm of precipitation.

Population figures have been updated based on growth rates in each country for the year 2002. Irrigation is the motor of development of the basin, especially in the valley and the delta. The raising of livestock has always been a major activity. After agriculture, fishing is the second largest economic activity of the basin

\section{Methods}

The methodology of the paper stresses a mix-scale approach anchored in geospatial information technologies of GIS and Remote sensing technologies based on the integration of primary data provided through government sources and data bases from other organizations. The raw spatial data and satellite images used in the research were procured through The United States National Aeronautical and Space Administration (NASA) and The United States Geological Survey (USGS).

\section{Step 1: Data Acquisition}

The first step involves the identification of the variables needed to assess environmental changes at regional level within a watershed. The variables consist of socioeconomic, physical and environmental information, including the amount of agricultural cropland, human settlement, water bodies, forest types, bare areas and shrubs, (See Tables 1 and 3). This process continued with the design of data matrices for the variables covering the various periods from 1979, 1987 and 1999 and beyond. In addition to the design stage, access to databases and abstracts that are presently available within the Government archives in Senegal basin countries, The United States National Aeronautical and Space Agency (NASA), a and host of other organizations helped facilitate the search process. The spatial data acquired from NASA consists of two Satellite images covering the Senegal River Basin area of West Africa for the separate periods of 1999, 1987 and 1979 as well as the data from the University of Maryland free online images.

\section{Step 2: Geo Spatial Data Acquisition and Processing}

For the study area of Senegal River basin, two satellite images: Landsat Multispectral (MSS), Landsat Thematic Mapper (TM) and Enhanced Thematic Mapper Plus (ETM+) multi-seasonal images of 30 September 1979, 10 October, 1987 and 11 September, 1999 were obtained for this study. All the images were processed using ERDAS IMAGINE 9.1 image processing software. The images for the basin imported into ERDAS as single band and were housed into ERDAS using ERDAS native file format GEOTIFF. All the bands were grouped together by employing ERDAS Layer Stack modules. This was followed by radiometric correction of all the images for variation in sun angle and atmospheric effects. Additionally all the images were geometrically corrected to remove, haze, scan lines and speckles; and referenced to the Senegal ground based coordinate system and Datum. Much of the basin's data for the 1979 image was coregistered with the 1987 and 1999 images, and later geolinked to allow for the subset of both images to the study area.

A linear stretch enhancement technique was performed on all the images, and later subset using ERDAS Area of Interest Tool (AOI) to emphasize the study area. Finally, image categorization was also performed using unsupervised classification techniques. The remaining procedure involves spatial analysis and output (maps-tables-text) covering the study period, using ARCVIEW GIS. Outputs for the region were mapped and compared cross time. This process helped show the extent of temporal-spatial evolution of ecological change induced by human activities along the Senegal River watershed.

\section{The Analysis of Environmental Change}

This part of the paper presents environmental analysis with focus on the results of the GIS and remote sensing analysis tracking the state of the ecosystem in the area and change over the years from a temporal and geospatial perspective. The analysis of the water use and climatic variability and hydrological discharges occurring in the area along with the impact assessment of development in the basin are also presented. 


\section{Temporal Analysis of Change}

The results of 1979, 1987 and 1999 classified images are shown in Figure 3-6 and Table 4 Figure 3 denoting classified Landsat MSS, TM, ETM+ images of 1979 shown in (A), 1987 in (B) and 1999 in (C) represent the actual raw images that were run through a classification process that resulted in the production and calibration of the various ecological features highlighted in Figure 4-6 along with the time series in Table 4 . The accuracy of the results was compared to available information on the study area. While the analysis points to a mix of gains and declines on the various ecological indicators from water bodies to human settlements, the classification in Table 4 shows that water bodies increased from the original figure of 90,000 in 1979 to 100,750 hectares in 1987 at an overall rate of 11.9 percent. In the ensuing year of 1999, the size of water bodies also rose to 105,000 hectares; this represents a 4.2 percent increase from the 1987 figures estimated at 100,750 hectares. Within the same periods, the size of forested land areas which opened at 120,140 hectares in 1979 dropped to 110,600 at a rate of about -8.6 percent in the 1987 fiscal year. The numbers later rebounded slightly to 2.5 percent between 1987 and 1999. In a similar vein the size of shrub land fell from 92,660 hectares in 1979 to 70, 250 hectares in 1987 and continued on the downward skid between 1979 through 1987 by 13.2 percentages points.

Table 4: Results of the classified Images 1979, 1987 and 1999

\begin{tabular}{|c|c|c|c|c|c|}
\hline Classes & $\begin{array}{c}\text { Area } \\
\text { (ha) in } \\
1979\end{array}$ & $\begin{array}{c}\text { Area } \\
\text { (ha) in } \\
1987\end{array}$ & $\begin{array}{c}\text { Area } \\
\text { (ha) in } \\
1999\end{array}$ & $\begin{array}{c}\% \\
\text { change } \\
\text { (1979- } \\
1987)\end{array}$ & $\begin{array}{r}\% \\
\text { change } \\
\text { (1987- } \\
1999)\end{array}$ \\
\hline Waterbodies & 90,000 & 100,750 & 105,000 & 11.9 & 4.2 \\
\hline Forest & 120,140 & 110,600 & 113,400 & -8.6 & 2.5 \\
\hline Shrubs & 92,660 & 70,250 & 60,950 & -24.2 & 13.2 \\
\hline Agriculture & 83,080 & 91,140 & 92,050 & 9.7 & 0.9 \\
\hline Bare Areas & 82,530 & 92,070 & 93,010 & 11.6 & 1.0 \\
\hline Settlement & 72,000 & 75,600 & 76,000 & 5.0 & 0.5 \\
\hline
\end{tabular}

Among the other variables under analysis in the study area, both agricultural land and bare surface areas posted identical levels of increases in the periods 1979 to 1999 . From the table, the farmers in the region used 83,080 hectares in the first period while the number increased to 91,140 and 92,050 hectares in the remaining periods of 1987 and 1999 at the rates of 9.7 and 0.9 percent respectively. In the same period, the size of bare areas varied by 82,530, 92,070 and 93,010 hectares at the rate of 11.6 and 1.0 percent respectively. The growing pressures mounted by human activities in the region can be evidenced by the initial size of areas with large concentration of people estimated at about 72,000 hectares in 1979. This was followed by an increase of 75,600 to 76,000 hectares in areas under human settlement between 1987 through 1999 at a rate of 5 to 0.5 percent for the study area.



Figure 3: Classified Landsat MSS, TM, ETM+ images of 1979 shown in (A), 1987 in (B) and 1999 in (C).

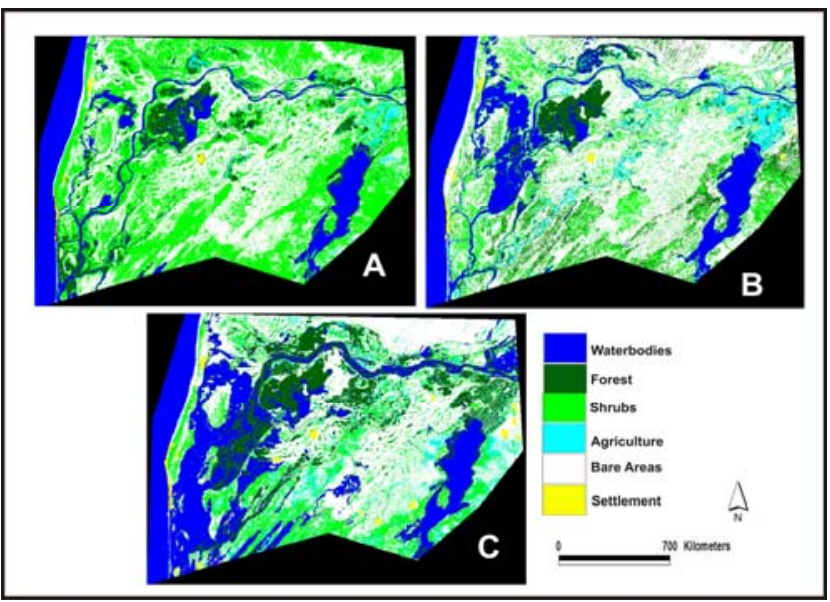

Figure 4: False-color image of Landsat MSS, TM, ETM+ images of Senegal Basin. 1979 image is displayed as RGB 231 in (A). The 1987 and 1999 images are displayed as RGB 742 respectively in $\mathrm{B}$ and $\mathrm{C}$.

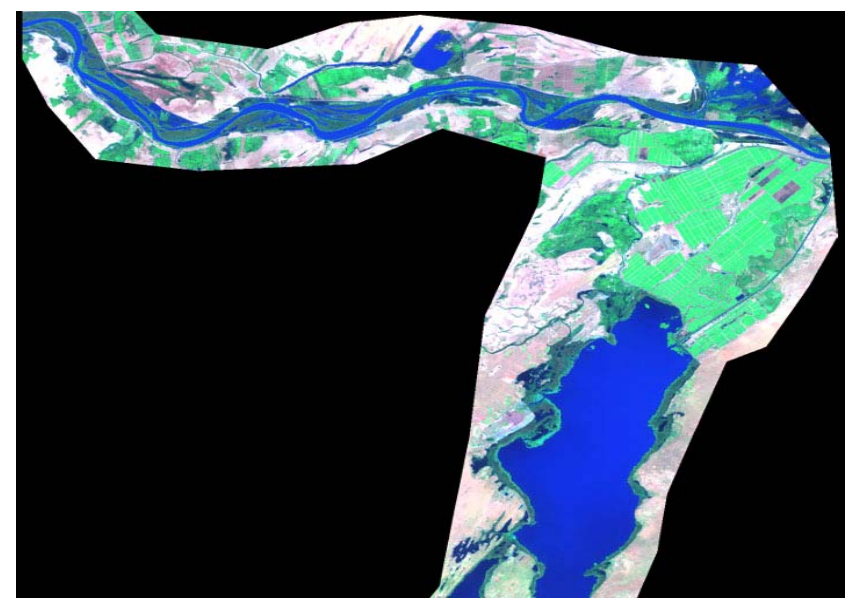

Figure 5: False color image of the 1999 Landsat ETM+ image of the irrigated areas in the Malian Section of the Senegal Lower Basin displayed as RGB 742 




Figure 6: False color image of the 1999 Landsat ETM+ image of the irrigated and forest areas in the Upper Senegal Basin displayed as RGB 742

\section{Spatial Analysis of Change}

The results of the geospatial analysis using integrated GIS and remote sensing technology in the study area point to evidence of the growing influence of climatic variability factors on the basin's surrounding ecology between 1979 through 1999. Beginning from the period 1979, as the classification of the land cover images in Figure $3 \mathrm{~A}$, indicate the impacts of environmental change are highlighted by severe drought features of dark blue color covering water bodies (made up of hydrology and estuarine features) along the region's upper and lower sides. Aside from the sizable pockets of areas covered with green space indicators of forests and shrubs with slight evidence of irrigated agriculture on the Malian and upper Senegalese side of the basin fully magnified in Figure 5-6, bare areas associated with desertification remained quite pronounced. All in all, the water features along the major protected areas and national parks on the upper valley of the basin bordering Senegal and Mauritania, Guinea and Mali appear dried with mostly bare surfaces during closing decades of the 1970s. This seemed to have occurred at a time when the area had limited dams and hydro projects for the diversion of water to different uses in the face of a gradual concentration in human settlements in the urban centers along the basin's Atlantic coast and other areas.

In 1987, as the map and images in the figure show, the study area appeared to have experienced a reversed climatic feature somewhat different from the previous year of 1979. The image reveals a gradual resurgence of networks of irrigated farming in light blue as well as water and estuarine features with much flooding represented in dark blue. This was followed by the light appearance of vegetative cover of forests and shrub land (green space) essential for biodiversity and species enrichment as well as bare surfaces thickly clustered along the region. With the size of the region's hydrological features and riparian corridors somewhat pronounced, the regional breakdown of the trends further reveals an amalgam of large riparian features on the Senegal-Gambia and Guinean portion of the south west area of the basin along the Atlantic as well as the Malian part of the South East. Further along the valley and the upper basin shared by Senegal, Mauritania and Mali, note the pace of heightened concentration of green patches in protected area habitats as built areas intensify their pressures on the basin's surrounding ecology. With time, the gradual reversal in climatic variability in the area partly brought about by the design of dams resulted in more agricultural activities through irrigation farming.

All through 1999, within the basin, there seem to be the presence of large clusters of riparian features based on the widening volume of surface hydrology and robust presence of green cover along the river catchments' as well as the sub basins. The spatial distribution of these features in the map though much more different and diffused than the previous years is evident on the lower edge along delta on the Atlantic region bordering Senegal, Gambia and Guinea Bissau where a much larger concentration of hydrological features easily distinguished in dark blue seemed more pronounced than the past years of 1979 and 1987. There exists also a recurrence of similar features on the Malian portion of the basin along the Guinean highlands. With the protected areas represented in green color on both sides of the basin visibly intact, the region experienced sustained spreading of vegetative and forested landscape covers and agricultural activities denoted in lighter green features in moderate patches on the basin's valley and the upper side separating Senegal, Mauritania and Mali. Notwithstanding, the emergence of these environmental features along the basin, there were still large presence of barren and bare surface areas along the central and deep south of the region due to desertification and deforestation. This came in wake of increases in human settlement and decline in some areas. With the importance of water access in the region's agriculture especially irrigation and fishing, the presence of dams and hydro electricity sites on the upper and lower part of the basin for irrigation, industrial and domestic uses appeared to have spurred the abundance of green spaces in some places and the presence of human settlements and irrigation farming in the Malian and the Senegal side of the basin.

\section{The Analysis of Water Use and Climatic Variability in the Basin}

Notwithstanding, some of the changes brought about in the region through irrigation and the design of hydro electricity dams and other practices in the preceding analysis, water continues to be in great demand among the countries in the Senegal River basin. For the purposes of conducting an environmental change analysis in multinational watershed management, the water consumption patterns of individual countries and the state of the resource merit some attention at this stage. In light 
of this, water use and seasonal changes in the Senegal River over the years are briefly highlighted.

\section{Water Use in the Region}

From the data on water use in the area presented in Table 5, agriculture stands as the biggest user among the various sectors. The breakdown of water consumption by sector shows agriculture to be the major user of water followed by domestic residence and industries. Among the individual countries, both Senegal and Mali appear to have used identical volumes of water estimated at 1360 million meters between 1987 while Mauritania consumed 1630 m3 more than its neighbors. While the diversion of water towards agriculture among the countries stayed in the order of 1319 million meters, for Mali, 1499 for Mauritania and 1251 for Senegal, their domestic use of water fluctuated intermittently by 27, 101 and 68 million meters respectively. Within the same time, industrial use of water in Senegal estimated at 41 million meters appears to have surpassed the 29 million meters consumed by Mauritania, and the 14 million meters used by Malians.

Table 5: Water use by sector within the OMVS area (in millions $\mathrm{m}^{3}$ )

\begin{tabular}{lccr}
\hline Sector & Mali & Mauritania & Senegal \\
\hline Agriculture & 1319 & 1499 & 1251 \\
Domestic Use & 27 & 101 & 68 \\
Industry & 14 & 29 & 41 \\
Total & 1360 & 1630 & 1360 \\
Per Capita (m³/year) & 161 & 923 & 201 \\
\hline
\end{tabular}

Reference year is 1987, except Mauritania (1985). Agriculture is by far the most important water user in the OMVS area.

\section{Climatic Variability and Discharges}

The pressures unleashed from climatic variability as mentioned before has been felt in the region since 1951 to 1991 in the form of seasonal changes in the volume of river discharge. Essentially, the basin had more discharges estimated at $2247\left(\mathrm{~m}^{3} / \mathrm{s}\right)$ between 1951-1971 during the rainy seasons, but only to drop heavily to $172(\mathrm{~m} 3 / \mathrm{s})$ in the dry season. Of all the years as Table 6 indicates, the period spanning through 1972 to 1990 not only emerged with fewest discharges from rain, but the region experienced its lowest levels of discharge in the driest season as well when compared to the other years. In that period, the region's discharge went from $999 \mathrm{~m}^{3} / \mathrm{s}$ in the rainy season to a marginal estimate of $71 \mathrm{~m}^{3} / \mathrm{s}$ ) in the dry season. Accordingly, the distribution pattern of seasonal river discharges clearly implies a long history of water stress along the region.
Table 6: Seasonal changes in Senegal River discharge since 1951

\begin{tabular}{lcr}
\hline Period & $\begin{array}{r}\text { Rainy Season } \\
\left(\mathrm{m}^{3} / \mathrm{s}\right)\end{array}$ & $\begin{array}{r}\text { Dry Season } \\
\left(\mathrm{m}^{3} / \mathrm{s}\right)\end{array}$ \\
\hline $1951-1999$ & 1538 & 138 \\
$1951-1971$ & 2247 & 172 \\
$1972-1999$ & 1007 & 112 \\
$1972-1990$ & 993 & 71 \\
$1991-1999$ & 1036 & 201 \\
\hline
\end{tabular}

This table clearly shows the benefit of the Manantali dam construction in the flow regulation (beginning 1991): the discharge never falls below $200 \mathrm{~m}^{3} / \mathrm{s}$.

\section{The Impacts of Development}

With the harsh climatic conditions in the area coupled with recurrent water stress, hydro projects in the region have had lasting impacts on the region's ecosystem. The outcomes are presented in two major themes under the rubric of agricultural development and negative environmental impacts.

\section{Positive Effects through Irrigation Agriculture and Hydro- Development}

Considering the huge hydro potentials in the basin (Varis 2002), it was not until 1973 that the state company for agricultural development opted to increase this capacity by building dikes covering 10,000 hectares of flood land which eventually resulted in the creation of 650 hectares of irrigated area in 1975. Thereafter, smaller irrigated areas were rapidly created as a means to combat the drought cycles in the 1970s [1, 23]. On the left bank of the basin, the surface area of community based irrigated agriculture fields grew from 20 hectares in 1974 to 7,355 hectares in 1983 and 12,978 hectares in1986. Just as the influence of irrigation agriculture rapidly expanded after the new dams were filled between 1986 and 1988. Toady irrigation remains the motor of development in the basin, notably in the valley and the delta, due to improved technology and the wider variety of produce grown. Of about 100,000 hectares of cultivated land in the basin, 60,000 hectares are devoted to farming operations during the rainy season the other 20,000 are used similarly during the dry season. In the context of what transpired over the years in region, it is evident that the development of dams has had some positive effects on the basin's population and natural resources. Accordingly, the installation of the dams has enabled a year round availability of freshwater in sufficient quantities, which resulted in the development of irrigated agriculture in the valley and access to drinking water installations for populations living near the dams, among the other things [1]. 
Negative Environmental Impacts

In the aftermath of hydro programs that occurred in the basin, the flood plain ecosystem experienced numerous ecological impacts. Much of the negative effects from development projects embody the displacement of the population, ecosystem degradation and the proliferation of water borne diseases which severely impeded the health of the local population. Aside from the menace of pollution attributed to the discharge of industrial and agricultural chemicals, other adverse ecological issues include the increased competition for agricultural land, firewood and over grazing from other land uses and the threats of heavy erosion emanating from the clearance of marginal land on the river banks. The degradation of the basin's ecosystem has also affected the river bank population to various degrees though the drop in the productivity of economic activities in the area of agriculture particularly livestock farming coupled with decline in income and standard of living. Additional challenges which the basin has had to face since 1993 and 1994 following the construction of dams involve water borne diseases that caused severe outbreak of malaria, urinary schistosomiasis, diarrhea as well as intestinal ailments [8, 11, 1, 16, 19, 21, 23].

\section{Management Framework and Mitigation Efforts}

To mitigate some of the problems that occurred in the region, the management framework adopted by the Senegal Basin authority has for years relied on mutual cooperation among the riparian states. This section of the paper, examines the framework guiding the management of the basin and efforts to reverse the emerging problems under five principal themes. The themes range from efforts to capitalize on the benefits to the ability to manage extreme hydrological conditions of the basin for the common good of the riparian states.

\section{Focus on Benefits and the Avoidance of Conflicts}

The Senegal River Basin countries' decision to cooperate marked a significant shift in how international river basins are developed. By choosing to develop the Senegal River jointly, Mali Mauritania and Senegal focused on generating the services they needed and then sharing them equitably. Referred to as the principle of benefit sharing, this approach is unique in that it focuses on benefits rather than allocations. By working as partners rather than competitors, the countries face their common challenges of reducing poverty and sustaining economic growth together. Under this principle Mauritania bears $22.6 \%$ of the cost of common infrastructure and receives $33.6 \%$ of the 375,000 hectares of land for irrigation and $15 \%$ of anticipated power generated under the terms of the agreed development program. Mali bears 35\% of the costs, receives $52 \%$ of all energy generated and remains the main beneficiary of the navigation program. Senegal which receives $64 \%$ of irrigated land and 33\% of energy, assumes more than $42 \%$ of the costs [25]. Such commitment to joint management and common works has cemented intra-basin relations built on the premise that benefits will be shared equitably and the country hosting the common works will respect their joint ownership without the treats of conflicts in the area.

\section{Provision of Infrastructure and Basin Needs}

Considering the relevance of basic necessities and infrastructure development in the basin, The OMVS countries created two types of shared infrastructures that transcend physical and institutional domains of governance. Under the framework, the physical components include water management works, telecommunication networks, and transportation links. Institutional infrastructure on the other hand, cover the OVMS and its related agencies, seeking to synchronize national planning and legal frameworks in order to promote trade and labor flows both of which are needed for the basin's development. With such framework in place, the proliferation of infrastructure such as dams that favored the development of portable water, electricity, and telecommunications in the valley and the other crucial geographical areas not directly situated in the basin, such as Bamako, Dakar and Nouakchott assumed grater significance in the strategic vision of the riparian states [24]

\section{Encouragement for Stakeholder Participation}

To encourage public engagement in decision making, the OMVS reached out to stake holders, by ensuring their representation on the Permanent Water Commission, OMVS consultative arm. As part of the process, local coordination committees were established in Mali, Mauritania and Senegal to allow communities to take part in decisions pertaining to transmission line routes from the Manatali Dam. Similarly, the Global Environmental Facility (GEF) program for the Senegal Basin doubled the number of such committees in all basin countries, including Guinea. Building on existing institutional structures and experiences in the Senegal Basin under GEF's Small Grants Program, the project will support microfinance opportunities by working with local communities at the key sites across the basin. Under the program, the four countries will each identify and prepare national priority action plans to ensure improvement in livelihoods and management of the basin's resources [24].

\section{Restoration of Lost Livelihoods and the Ecosystem}

In a region known for severe ecological disasters and marginal standards of living, work has been taking place along the basin to restore ecological diversity and rural livelihoods impacted by droughts and alteration of river flow. In response, Mauritania and Senegal jointly established Djoudj National Park (in 1971) and Diawling National Park (in 1991) on their sides of the river 
respectively. To reverse ecosystem decline, Diawlling National Park authorities, initiated a program that integrates conservation with development. Under the program, a multidisciplinary team of experts worked closely with local communities integrating knowledge of ecosystem functions into the proposed park's Management plan. In the process, the team recognized that the preDiama Dam flood cycle would need to be restored for local people to resume their traditional activities or develop new ones such as ecotourism and market gardening. There were also efforts to support local fisheries and wildlife population. The regeneration of fishery came with the addition of two slice gates to allow fish migration through and from the spawning grounds in the Diwaling-Tichilit basin while the boosting of food levels resulted in an increase in wild life from an initial level of 2,000 water birds in 1993 to 50,000 in 1995. With efforts upstream to mitigate the environmental impacts of the Manatali dams under a regional plan, the threats of invasive weeds along the Senegal delta received major attention in 2003 under a $\$ 6.6$ million plan funded by the Senegalese government to clear 1.3 million square meters [24].

\section{Management of Extreme Hydrological Events}

Building under a common physical and institutional infrastructure, that includes shared collection of hydrological data. Mali, Mauritania, and Senegal work together to manage the threats of extreme events such as floods and droughts. To ensure ecological welfare, hydrological data are transmitted simultaneously by satellite to OMVS headquarters in Dakar, to SOGEM at Manatali Dam, to SOGED at Diama Dam, and to national water companies in Bamako, Dakar and Nouakchott. Each receiving station has the same modeling software to determine the necessary actions in the event of unusual water flows. Considering the essence of coordinated response in minimizing the loss of life and socioeconomic damages in arid environments, in 2003 when the basin experienced floods of a severity not seen before in a country, damage to the basin's economy and the impact on poverty was reduced by OMVS, efforts in coordinating the countries' technical efforts, and by using local radio networks to keep communities along the river informed. The handling of the situation contrasts sharply with what happened in Mozambique in 2000 where the real GDP declined by $23 \%$ after massive flooding. Much of the damage in Mozambique could have been avoided by better cooperation among the riparian countries as commonly practiced by the Senegal River basin nations [24].

\section{Discussions}

Notwithstanding the extent of institutional response and collaboration through the design of dams and irrigation to mitigate harsh climatic variability and the impacts of water development projects, the OMVS nations of the Senegal River still face numerous constraints in containing the recurring disasters. It is evident that the constant barrage of severe climatic conditions and environmental change threatens the surrounding ecology of the Senegal Basin states of Mali, Mauritania, Senegal and Guinea. The GIS and Remote Sensing analysis indicate an increase in water-bodies, human settlement, agriculture and bare areas coupled with declines in forest and shrub areas. In the area, water bodies rose at different rates from 1979-1987 and between 1987 -1999. Both forested and shrub areas posted initial declines and later rebounded. Within the same time, some areas under shrubs showed slight decrease as human settlements, irrigated agricultural land use activities and bare areas increased respectively over the years.

The impacts on the ecosystem can be evidenced with the widespread use of agrochemicals and pollution of riparian habitats, desertification and the emergence of other environmental problems. Furthermore, the continuous rise in population is expected to compound the critical state of water availability if not dealt with dispatch. This will not only threaten the carrying capacity of an already fragile ecosystem, but it poses enormous challenge for natural resource managers and policy makers. The incidence of change which is attributed to pressures from demography and natural forces and river development resulted in more irrigated areas to meet the needs of inhabitants of the basin coupled with the threats of desertification from the encroachment of bare areas. In the context of the study area, multinational watershed management based on regional cooperation is quite essential for conservation and the analysis of framework for shared waters in arid areas of West Africa. Because of the common experience, the Senegal Basin model of cooperation seem anchored in mutual trust and equitable share of water resources without the conflicts found in other areas of Africa.

Notwithstanding the good intentions of the Senegal River Basin Authority in ensuring multinational management of the basin for member states to sustain their agricultural and power sector through access to water for irrigation, food security and hydro electricity. The results of the environmental and hydrological analysis of the trends using a set of ecological, socio-economic and physical indicators found the ecosystem of the Senegal River on the lower and upper side under water stress with some abundance in hydrological features due to irrigation and the development of dams. There were also negative environmental impacts from the hydro projects, this includes, the incidence of pollution caused by the discharge of industrial and agricultural chemicals into the environments. The other negative ecological externalities consist of pronounced competition for agricultural land, firewood and over grazing from other land use types and the menace of severe erosion.

To form a common front in the mitigation of problems facing the region, the Senegal Basin authority adopted a planning framework built on the principles of mutual cooperation under five major themes. The themes 
cover efforts to promote the benefits of the cooperation agreement, ability to manage extreme hydrological conditions of the basin for the common good of the riparian states, infrastructure provision for member states, restoration of the ecosystem and rural livelihoods and the encouragement of stakeholder participation among citizens of the riparian states.

\section{Recommendations}

To address the issues identified in the study area, the paper offers five major recommendations for the sustainable management of the basin. The suggested areas for future lines of action to boost international management of the river basin consists of the need to adopt geospatial information systems, commitment to mitigate the recurrent environmental hazards, integration of ecological and economic variables in water projects, the development of regional environmental data infrastructure and the provision of more funding for international water projects.

\section{Encourage the Adoption of Geospatial Information System}

The analysis in the study area pertaining to the multinational watershed management brought to the surface, the problems of drought, climate change, population growth, deforestation and the threats posed to life support systems along the riparian states. Considering the severity of drought and limited access to water for agriculture and the demand in the fastest urban centers, the need for a continuous use of geospatial information system as a decision support system for policy makers in the assessment of life support indicators in the region is now more important than ever. Access to the latest advances in spatial information systems offers a sizable advantage to those who have it and hinders the readiness of those who lack it in tackling the problems facing the region. Because the study of multinational watershed management along the Senegal River basin cannot operate in a vacuum in the absence of access to well designed spatial information systems, the paper recommends the regular adoption of these tools for sustainable management of environmental resources in the region [27,28 29].

\section{Mitigate The Recurrent Environmental Hazards In The Basin}

For years the Senegal River Basin has been experiencing various kinds of environmental problems that are related to transnational water management. This includes the flow of trans-boundary pollutants and toxic materials in the form of domestic and industrial effluents from the river banks of the coastal adjoining cities in the four countries as climate change, the threats of desertification and loss of green space intensify. The heavy concentration of pollutants along the riverbanks not only threatens marine life, biodiversity but it overstretches the carrying capacity of the ecosystem with serious impacts on the citizens. Because most of the environmental problems that afflict these riparian states put enormous strain on their quality of life and the ability to confront these issues individually. The paper recommends that concerted efforts be made in these areas in order to mitigate the recurrence of environmental problems [30].

Integrate Nature Protection Principles in Water and Hydroelectric Projects

The states in the Senegal River basin have over the years initiated hydro projects to ensure the supply of water for irrigation and hydro electricity for the betterment of quality of life and access to water in the area. In as much as the projects have strengthened access to water supply in the region's arid environment, the ecological and social costs on the basin threaten the localities. This can be manifested with widespread cases of displacement of citizens as a result of minimal environmental assessment prior to the execution of hydro projects. In light of that, the paper suggests the need for the adoption of stricter environmental standards for project designers so that the implementation of water programs is in sync with the tenets of nature protection. Doing so will help minimize the threats of environmental disasters emanating from hydro projects in the basin [31].

\section{Develop Regional Environmental Information System}

During the writing of this paper, there were very little data on the study of watershed management in the Senegal River basin area. Such void in information hampers the ability of the managers in the region to calibrate various scenarios of climate change, drought, environmental degradation, deforestation and pollution. Because decision makers and multilateral donors in the region cannot manage environmental resources efficiently without periodic access to a central data infrastructure, there is a need for the development of a regional environmental information system to ensure the management of the basin's natural resources. The proposed regional data infrastructure should contain information on physical, socio-economic, ecological and demographic elements driving change in the basin's ecology. Access to such information will sharpen efficient the tracking of environmental change in the region. It also provides opportunities to anticipate the ensuing disasters, in view of that the paper recommends the design of a regional environmental information system [27- 29].

Provide More Funding For Multinational Projects In The Basin

The Senegal River basin nations are classified as some of the poorest or poverty stricken areas of the world where most citizens live under some the harshest climatic conditions in the Sahel ecozone As an area where most 
people live on the margins including the governments, dealing with basic economic problems ravaging the area and the ensuing ecological problems not only becomes daunting task, but they are also quite challenging. Such constraints diminishes the readiness of nations in the region to single handedly confront the problems facing them without external aid agency support. Seeing the way financial aid and project assistance from multilateral agencies drive the management of natural resources in the region, the paper recommends the continuous infusion of more assistance from International Development agencies such as UNDP, the World Bank and those in the European Union, the United States and Canada. This will help alleviate the current hardships in the trans-boundary management of the basin's watersheds [31].

\section{Conclusion}

This paper has presented the applications of GIS and remote sensing tools in the analysis of multinational management of watershed in the West Africa region with a focus on the assessment of multinational management of shared waters of the Senegal River basin. The paper outlined an overview of the issues in the literature pertaining to the basin, the essence of Geospatial Information System, the current experiences and the state of the environment along shared waters at the multinational level. This was followed with an outline of the situation in the Senegal River watershed of West Africa with some emphasis on climatic variability along the Senegal River Basin, the essence of GIS and remote sensing based approach. Others include the analysis of environmental and hydrological change, the impacts of development projects, management framework and the future lines of action for mitigating ecological change in the basin.

Having said these several important conclusions can be drawn from this study. Aside from the harsh climatic variability and the constraints of multinational watershed conservation and cooperation among Senegal Basin nations at the expense of geospatial approach, integrated GIS and remote sensing applications point to a mix of gains and declines in environmental features. While there were increases in water bodies, settlements and agriculture, the emergence of stress indicators of population, and bare area pose a growing threat to the availability of water and conservation efforts in the Senegal River Basin. With remote sensing and GIS in the forefront of recent technological advances, the management of shared waters such as the Senegal River watershed will continue to be strengthened. This capability remains indispensable in the design of data infrastructure best suited for watershed analysis and conservation. Accordingly, GIS and remote sensing techniques as used here provide decision support mechanism for managers in the assessment of environmental hazards associated with multinational watershed management among the nations in Southern hemisphere. Judging from the trends in the study area, the incidence of change seems predicated on pressures from demography, natural forces and the proliferation of river basin development which resulted in more irrigated areas to meet the needs of inhabitants of the basin. With the substantial increase in bare surface areas in the region, the basin faces more threats from desertification.

Accordingly, the management initiatives of the Senegal River Basin region seemed compounded due to the growing threats of climatic hazards in the form of drought and periodic decline in the basin's hydrology and meager access to data for analyzing the impacts of change. The lack of geo-spatial analysis which diminishes the ability of managers to predict the extent of ecological costs of hydro projects in the region can be remedied by drawing from the current advances in geospatial information systems in the management of shared resources waters in the region along with the other set of recommendations that were herein outlined. This approach remains pertinent as the Senegal River Basin nations continue to consolidate their framework of multi-national watershed management as a conduit for continuous water access and food security and mitigation in the region. In light of this finding, the practical use of a mix scale approach involving the use of GIS and remote sensing in analyzing environmental and hydrological changes stand as an update to current literature on multi-national watershed management of the Senegal River Basin. Considering the little emphasis in the literature to assess the state of the environment and other issues facing the Senegal River Basin, the applications of geospatial technology as demonstrated in this paper served vital purpose in providing spatially referenced data for mapping hydrological and environmental trends by indicating the level of changes in managed waters of the basin. The paper also provides the preamble necessary in the design of geospatial decision support tools for the management of multinational waters in the Sahel environments of West Africa in the years ahead.

\section{References}

1. Lahtela, V.: Managing the Senegal River: National and Local Development Dilemma. International Journal of Water Resources Development. 2003, 19(2), 279-293.

2. Varis, O.: The River Senegal Case: Case Study For 2006 HDR Finland: The Helsinki University of Technology, Vantaa, 2006, 1-10

3. Biswas, S.: Remote Sensing and Geographic Information System Based Approach for Watershed Conservation. Journal of Surveying Engineering, 2002, 128: 3,108, 17.

4. Khawlie, M.: Watershed characteristics, Land Use and Fabric: The Application of Remote Sensing and Geographical Information Systems, Lakes and Reservoirs: Research and Management, 2005, 10, 85-92.

5. Usery, E.: Geospatial Data Resampling and Resolution Effects On Watershed Modeling: A Case 
Study Using The Agricultural Non-Point Source Pollution Model. Journal of Geographical Systems, 2004, 6(3), 289-306

6. Merem, E.: Twumasi, Y.: Hydropolitics: A Case of The Niger River Basin, GIS Development Magazine, 2006, 1-5

7. Varris, O.: Lahetela, V.: Integrated Water Resources Management Dilemma along the Senegal River: Introducing an Analytical Framework. International Journal of Water Resources Development, 2002, 18(4), 501-521

8. N' Diaye, M.: Dam Construction In The Senegal River Valley and The Long Term -Socio Economic Effects: Knowledge, Technology and Policy, 2007, 19(4), 44-60

9. Organisation Pour La Mise En Valeur Du Fleuve Senegal; Organization for the Development of the Senegal River (OMVS). High Commission, Dakar, Senegal: 2007, 449-462

10. Venema, D.: Evidence of Climate Change in the Senegal River Basin. International Journal of Water Resources Development, 1996, 12(4), 531-546

11. Diop, S.: Implication of Dams on the Fresh Water and Coastal Environment and Its Resources in Senegal. World Commission on Dams. , 2006, 107, 1-3

12. United Nations Development Program (UNDP). Human Development Report. UNDP New York: NY, 1999.

13. United Nations Center for Human Settlements. An Urbanizing World, Global Report on Human Settlements. Oxford University Press, Hong Kong. 1996

14. Prakash, A.: Deciding Alternative Land Use Options In a Watershed Using GIS. Journal of Irrigation and Drainage Engineering, 2007, 133(2), 162-174

15. Ringius, D.: Climate Change in Africa Issues and Challenges in Agriculture and Water for Sustainable Development. Oslo, Center for International Climate and Environmental Research, University of Oslo, 1996, Report 8.

16. Varis, O.; Fraboulet, J.: Water Resources Development in The Lower Senegal River Basin: Conflicting Interests, Environmental Concerns and Policy Options. International Journal of Water Resources Development, 2002, 18(2), 245-260

17. Daffe, M.: Senegal Left Bank Master Plan, Biodiversity in Development Project Case Study. London, UK: World Conservation monitoring center, 2000, 7, 1-5.

18. Boubout, A.: Presentation at Workshop in Djoud National Park, Senegal, 2001, (March 26).

19. Haefele, S.: Spatial Variability of Indigenous Supplies for N, P and K and its Impact on Fertilizer Strategies for Irrigated Rice in West Africa. Plant and Soil, 2005, 270, 57-72.
20. Ernould, J.: The Impact of the Local Water Development Programme on the Abundance of Schistosomiasis in Three Villages of the Senegal River Delta. Annals of Tropical Medicine and Parasitology, 1999, 93(2), 135-145

21. De Clercq, D.: The Effects of Irrigated Agriculture on the Transmission of Urinary Schistosomiasis in the Middle and Upper Valleys of the Senegal River Basin. Annals of Tropical Medicine and Parasitology, 2000, 94(6), 581-590

22. Ghedin, E.: Quality of Drinking Water Sources in the Two Sub Desert Sahelian Areas in North-Western Senegal. Int. J. of Environ. Studies, 1993, 44, 113-150.

23. Degeorges, A.: Dams and Large Scale Irrigation on the Senegal River: Impacts on Man and the Environment. Int. J. of Environ. Studies, 2006, 633-644

24. Alam, U.: West Africa - A Regional Approach to Reducing Poverty in the Senegal River Basin. The International Bank for Reconstruction and Development- The World Bank, Washington, D.C. 2000, 1-30

25. Niassse, M.: Update On The Management of Shared Water Courses the Senegal River Basin. IHDP Update. World Commission On Dams, South Africa, 2001, 1-2

26. Global Environmental Facility Fund (GEF). Senegal River Water and Environmental Management Project. Micro Grant Program - Priority Actions, Water and Urban Sector, Africa Region Office. 2002 (November), 2, 1-7

27. Xiao, H.: Relating landscape Characteristics to Nonpoint Source Pollution in Mine Waste-Located Watersheds Using Geospatial Techniques. Journal of Environmental Management, 2007, 82(1), 111-119

28. Lant, C.: Using GIS-Based Ecological-Economic Modeling To Evaluate Policies Affecting Agricultural Watersheds. Ecological Economics. 2005, 55(4), 467- 484

29. Sivanpillai, R.: Benefits of Pan-sharpened Landsat Imagery for Mapping Small Waterbodies in the Powder River Basin, Wyoming, USA.. Lakes and Reservoirs: Research and Management. 2008, 13(1), 69-76

30. Venema H.: A Water Resources Planning Response to Climate Change In The Senegal River Basin. Journal of Environmental Management. 1997, 49 125-155

31. World Bank Senegal River Basin Water and Environmental Management Project: Environmental Assessment, D.C.: Washington, African Water and Urban Department 2002, 1, 1-2.

32. Tyson, B.: Layering Natural Resource and Human Resource Data for Planning Watershed Conservation Strategies. Society and Natural Resources. 2004, 17(2), 163-170. 